\title{
THE TIPPING POINT
}

\section{How Decades of Unrest Culminated in the Humanitarian Crisis of Venezuela Today}

JORGE MEJIA

THIS ESSAY PROVIDES A RIGOROUS AND READABLE BACKGROUND TO WHAT IS PERHAPS THE MOST PRESSING GEOPOLITICAL ISSUE IN TWENTY-FIRST-CENTURY LATIN AMERICA: THE HUMANITARIAN CRISIS UNDER PRESIDENT NICOLÁS MADURO OF THE UNITED SOCIALIST PARTY OF VENEZUELA (PSUV). TO THIS END, IT ANALYZES AND CONNECTS THREE DISTINCT POLITICAL PHENOMENA IN VENEZUELAN HISTORY WHOSE INTERRELATED DEVELOPMENT UNDERPINS THE COUNTRY'S CURRENT INSTABILITY: PUNTOFIJISMO (1958-1998), CHAVISMO (1998-2013), AND MADURISMO (2013-PRESENT). IT FIRST DESCRIBES THE COLLAPSE OF PUNTOFIJISMO, VENEZUELA'S STYLE OF PACTED DEMOCRACY AND ITS OIL-DEPENDENT PETRO-STATE TO CONTEXTUALIZE THE RISE OF HUGO CHÁVEZ'S POLITICAL PROJECT IN 1990 KNOWN AS BOLIVARIANISM. THE PAPER THEN CONSIDERS CHÁVEZ'S REGIME AND HOW IT CONTINUED AND RUPTURED WITH PUNTOFIJISMO THROUGH CLIENTELISM, EXCLUSIONARY POLITICS, AND THE CREATION OF AN ILLIBERAL HYBRID REGIME. UPON THIS FOREGROUND, THE PAPER SITUATES THE CURRENT STUDENT PROTESTS, MILITARY REPRESSION, AND HUMANITARIAN CRISIS UNDER PRESIDENT MADURO. USING BOTH ENGLISH AND SPANISH-LANGUAGE SOURCE MATERIAL, THIS PAPER LAYS BARE THE CURRENT COMPLEX REALITY THAT IS VENEZUELA. 
9 "Today, Venezuela is the sick man of Latin America." ${ }^{\text {I }}$ So observes Moisés Naím, Distinguished Fellow at the Carnegie Endowment for International Peace, regarding the humanitarian crisis in Venezuela under current President Nicolás Maduro Moros of the United Socialist Party of Venezuela. The country's crisis-distinguished by food shortages, political instability and hyperinflation, among other things-has garnered the attention of observers worldwide. But this rediscovery of Venezuela does not mean that this situation was altogether unexpected. In fact, contemporary politics in Venezuela are the culmination of longstanding regime characteristics that persist from Venezuela's transition to democracy in I958. From 1958 to 1998 , Venezuela functioned as a pacted democracy (partidocracia) and oil-rich petro-state (petroestado) - an arrangement called Puntofijismo. An oil bust in the early I980s, however, undercut this system, while also opening a window of opportunity for a reformist political project to overhaul the regime with an alternative state ideology, administrative structure, and economic program-that of former President Hugo Chávez's Bolivarianism from 1998 to 2013 . Upon his death in 2013 , Chávez left behind a legacy of clientelism and exclusionary politics for his successor and current President of Venezuela, Nicolás Maduro-a period of political repression known as Madurismo. This backgrounder, however, shows that Maduro's autocratic rule was not unexpected. Since the mid-twentieth century, Venezuela has always changed in structure, but seldom in content.

To talk about Venezuela today is to first discuss the collapse of the system of public governance that characterized Venezuela from I958 to 1998: Puntofijismo. Daniel Hellinger writes, "Most of the recent works on Venezuela concentrate on the collapse of the Punto Fijo system and on the character of Chavismo and the Bolivarian government." ${ }^{2}$ Venezuela's transition from the military dictatorship of Marco Pérez Jiménez to democracy arrived in I958 after representatives of Venezuela's three main political parties-Democratic Action (AD), the Social Christian Party (COPEI), and Democratic Republican Union (URD) - signed a formal agreement to accept the results of the December 1958 presidential election of $\mathrm{AD}$ candidate Rómulo Betancourt. This "Pacto de Punto Fijo" enshrined what political scientists term "consociational democracy," a power-sharing arrangement whereby parties agreed to alternate the presidency, respect election results, equally apportion government agency positions, and prevent single-party hegemony. ${ }^{3}$ Equally, it affirmed petroleum's dom- inance in the economy. The resulting institutional arrangement is referred to as Puntofijismo.

Puntofijista democracy had several important characteristics that contextualize the subsequent erosion of Venezuelan democracy. Scholars of Venezuelan history have underscored two especially defining qualities - the notion of the "petro-state" and "partyarchy" (or pacted democracy). Terry Lynn Karl is authoritative on the former with her 1997 book, The Paradox of Plenty. Karl defines a petro-state as the distinctive type of institutional setting produced by an outsized dependence on petroleum revenue. ${ }^{4}$ Petro-states such as Venezuela are noted for their extractive and distributive state capacities. More importantly, s-uch reliance on non-productive and capital-intensive resources, more importantly, affects political arrangements. Indeed, oil dependence influences social classes, regime types, state institutions, as well as the decision calculus of policymakers. Regime type is especially subject to oil dependence due to the "symbiotic interaction between the...incentives created by the petro-state and a particular type of democracy." The latter hints at the second aforesaid characteristic of Puntofijista democracy: "partryarchy," a coinage of Michael Coppedge in his 1997 book, Strong Parties and Lame Ducks. ${ }^{6}$ This refers to Venezuela's post-transition tradition of corporatist elite bargaining, intra-elite compromise, and economic conservatism in managing petroleum revenues and state-society relations. ${ }^{7}$ As Hellinger notes about AD and COPEI's talks at Punto Fijo, "The issue was not whether some type of system would be better...than democracy, but whether this particular democracy was delivering on

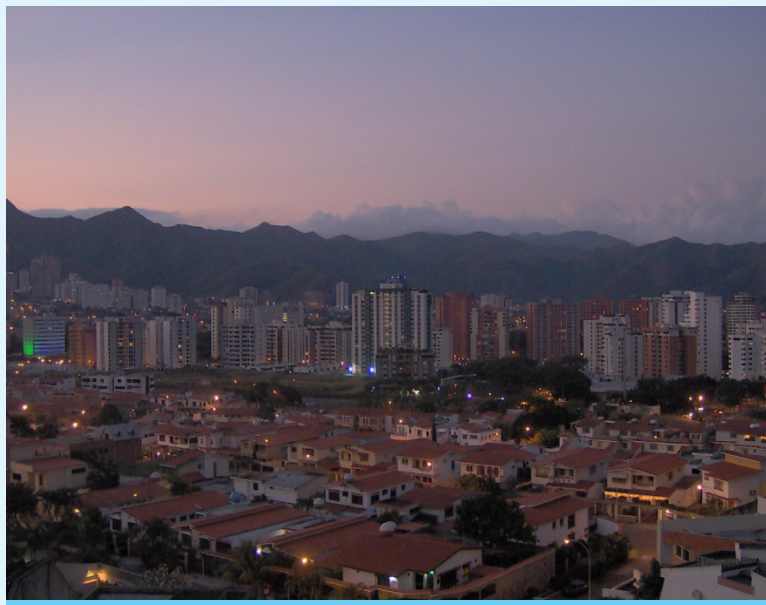

THE CITY OF VALENCIA, VENEZUELA AT SUNSET(COURTESY OF WIKIMEDIA COMMONS) 


\section{"[T] opposite directions in oil-rich states."}

the promise of 'sowing the oil' in a project of national development that would include all Venezuelans." ${ }^{8}$ From I958 to I979, Venezuela's petro-state and pacted democracy resulted in a system of consistent economic growth, strong political parties, and governability.

During the I980s, this stability began to erode. Equally important, the events constituting this erosion explain the reason for which Hugo Chávez and his ideology of Bolivarianismo (Bolivarianism) successfully channeled this institutional anomie and social demand into a revolutionary political platform. In his 2002 article, "The Decline and Fall of Democracy in Venezuela," Daniel Levine notes that the synergy between the dynamics of the petro-state and the machinations of pacted democracy reinforced certain systemic ills in Venezuela, such as corruption, truncated political participation, corporatism, patronage, presidentialism, and bureaucratization. Thomas Friedman captures these ideas in his famous "First Law of Petropolitics," which posits that the price of oil and the pace of freedom move in opposite directions in oil-rich states. ${ }^{9}$ Indeed, in I983, when oil prices dwindled, the stability of these arrangements weakened. Several events followed that foreclosed the legitimacy of Puntofijismo. Among these is the Caracazo, the Caracas-based riots of February 27, 1989 in response to the government's structural adjustment program. Equally crucial were the attempted military coups of I992 on February 4 (led by then-military lieutenant Hugo Chávez) and November 27, coupled with the December I993 impeachment of former President Carlos Andrés Pérez (who abandoned COPEI and won on an anti-party platform). Levine explains the implications of these events for Venezuela's Puntofijista democracy:

At each of these points a key pillar of the system was undermined or removed: economic strength (Black Friday); social pacts, control, and civil order (27 February); a depoliticised and controlled military (4 February and 27 November); and unquestioned executive dominance and party hegemony (the destitution of Pérez and the election of Caldera). The nature of the crisis reflects the dimensions of decline: economic decay, political ossification and immobilism, and rising protest. ${ }^{\text {o }}$

Evidently, the I980s issued a terminus to Venezuela's Puntofijista democracy. The qualities of petro-state and pacted democracy-economic growth, stability, governability, controlled organized social life, and military subordination to civilian rule-were no longer guaranteed. Factionalism, social outcry from civil society, and polarization were underway.

This collapse of Puntofijismo ran parallel with the emergence of an alternative political project of special relevance to contemporary Venezuela: Hugo Chávez's Bolivarianismo. To be precise, Bolivarianism refers to the political thought embodied in the military movement called the Movimiento Revolucionario Bolivariano (MRB), involved in the aforesaid coup d'état against President Carlos Andrés Pérez in 1992. In his essay, "Explaining Political Change in Venezuela," Pedro Sanoja observes, "The ideas of Bolivarianism are derived from contradictions inherent to existing institutions, and can only be understood in relation to the values and practices embedded in them, which Bolivarianism aimed to replace." ${ }^{\text {II }} \mathrm{He}$ is referring to the opportunities presented by the decay of the Puntofijista institutional order. These opportunities include the inability of AD and COPEI in the corporatist pre-Chávez institutional setting to placate social demands. This breakdown of social consensus is seen in the rise of civil society groups during the I980s, such as human rights organizations, barrio (district) associations, local church groups, and insurgent unionism, all assuming an anti-establishment disposition. ${ }^{12}$ Coincident with this social activism was party disaffiliation and competing political programs alongside Chávez's MRB, such as Convergencia and Causa $R .^{{ }^{13}}$ This political opportunity is what Laclau terms a "populist rupture." ${ }^{14}$

Hugo Chávez's ideology of Bolivarianism successfully channeled this opportunity into a political project. Sanoja provides a useful analysis of such ideology. Chávez's Bolivaranism invokes the philosophies of figures from Igth century Venezuela, specifically the "Trinity" of the Liberator, Simón Bolívar, his tutor, the pedagogue Simón Rodríguez and Ezequiel Zamora, a military leader during the Independence Wars (I8IO-I823). It also incorporates Rousseauian notions of direct democracy, socialism, Christian-

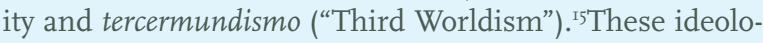
gies amount to an effective critique of Puntofijismo. ${ }^{16}$ This project critically recognized civil society's unifying plea- 
the overhaul of Puntofijista democracy-by linking the Venezuela of 1830 with the Venezuela of 1990 so as to paint an unfinished Manichean struggle for freedom. In short, Chávez's Bolivarian ideology during the I990s made strategic use of anti-Puntofijista civil society demand. Ultimately, Bolivarianism-and its repudiation of pacted democracy-became institutionalized in December I998, when Hugo Rafael Chávez Frías of the United Socialist Party of Venezuela (PSUV) became the democratically elected President of Venezuela.

Hugo Chávez's fifteen-year-long administration (I9982013) was distinguished by a reformist rupture with previous institutional arrangements, but also a continuity with past governance structures, norms, and practices. This duality, while seemingly contradictory, helps to situate contemporary Venezuela within its prior development (e.g., pacted democracy and a rentier economy), but also account for contingencies (e.g., Chávez's I999 constitutional reform and regime hybridity). This perspective, as will be shown, allows for a more complete understanding of the current humanitarian crisis in Venezuela under President Nicolás Maduro.

Interestingly, Chávez's government shared several characteristics with the Punto Fijo system. According to Julia Buxton, "While the political crisis has been...portrayed as a new phenomenon that emerged as a result of Chávez's policy programme and style of government...the conflict has deep historical roots and...has been shaped by the legacy of political organisation in the pre-Chávez era." One such legacy or continuity is what Buxton calls the "politics of exclusion." She views the policies and social constituency of Chávez and Chavismo as a product of the state apparatus molded by the historically dominant parties (AD and COPEI) - of rent distribution, inter-elite compromise, restricted political choice, and oil dependence. Indeed, Puntofijista governance relied on restricted access to the state. Venezuela's "Fourth Republic" prevented the poor from organizational representation-the Confederación de Trabajadores de Venezuela (CTV), for instance, concentrated welfare benefits among urban workers affiliated to Democratic Action. ${ }^{18}$ Buxton asserts that Chávez's "Fifth Republic" while increasing electoral access to the politically disenfranchised such as Afro-Venezuelans, also excluded beneficiaries of the partidocracia such as urban elites. Exclusionary politics, of course, is just one continuity from the pre-Chávez era into the Chávez era.
Other continuities under Chávez's regime relate to the economy. Specifically, the nature of the Venezuelan economy under Chávez reflected the one that preceded it since the I920s: the oil-dependent petro-state, which some scholars refer to as "rentier socialism." ${ }^{19}$ The Council on Foreign Relations reports that today, as under Chávez, oil accounts for about 95 percent of Venezuela's export earnings. ${ }^{20}$ Enjoying international prices of over \$IIO a barrel, while also never creating a reserve fund for future oil busts (as Kuwait and Norway have done), Chávez continued rentier policies unabatedly. After dispatching I8, 000 employees from Petroléos de Venezuela (PDVSA), the state's oil company, in 2003 , he initiated a number of misiones bolivarianas ("Bolivarian missions"), social programs aiming to eradicate short-term social ills, such as Misión Mercal (fighting food scarcity) and Misión Barrio Adentro (providing free preventative primary care in poor working-class neighborhoods). ${ }^{21}$ For that reason, Buxton notes, "Chávez is very much a symptom...of the political crisis in the country." ${ }^{22}$ Evidently, Chávez's regime partly continued the legacy of Puntofijismo, such as the exclusionary politics and rentierism.

However, Chávez also departed considerably from Puntofijismo in several ways. According to Javier Corrales in Dragon in the Tropics, Chávez's constitutional reforms constructed a "hybrid regime." ${ }^{23}$ The first change Chávez made in 1999 was to rewrite the I96r Constitution into the Bolivarian Constitution of Venezuela (CRBV). ${ }^{24}$ This document monumentally reorganized political life. It provided for recall referendums for public officials, replaced the bicameral legislature with a unicameral National As-

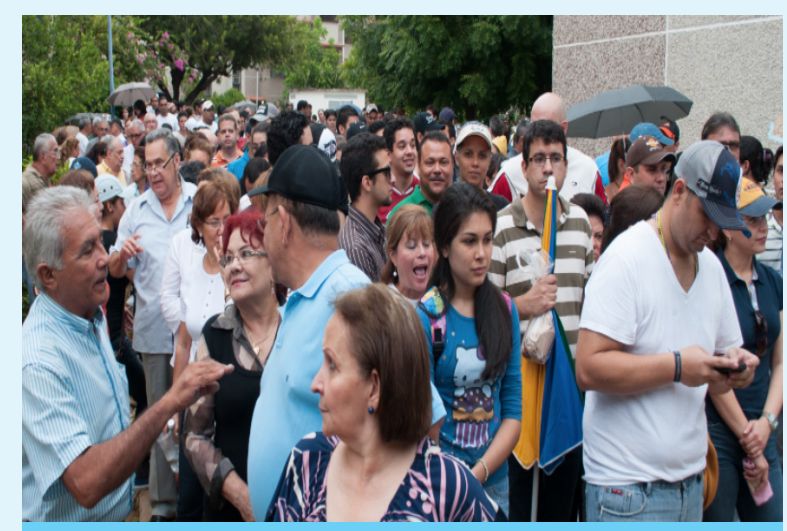

THE QUEUE TO ENTER THE POLLING STATION IN THE PRESIDENTIAL ELECTION OF 2012 IN VENEZUELA (COURTESY OF WIKIMEDIA COMMONS) 


\section{"The vicious circles of pacted democracy and the petro- state have conditioned the calculus of Maduro's decision- making-what some Latin American observers have termed Madurismo."}

sembly, lengthened the presidential term to six years from four, and allowed for re-election of the president. These amendments, Corrales argues, foreclosed pacted democracy in Venezuela, allowing for increased access for the politically disempowered, but they also transformed the country into a hybrid regime. These are political systems that combine democratic traits (e.g., free elections) with autocratic ones (e.g., political repression). ${ }^{25}$ The I999 Constitution allowed for Rousseauian council-based democracy, but also created a "high-stakes" political system that reduced checks and balances and centralized political leadership. The advantages of holding executive office were indeed heightened, but the cost of remaining in the antiChavista opposition proved increasingly overwhelming because state resources were deployed to party loyalists. Such clientelism or opportunistic social spending, Corrales posits, results from increased political competition and declining institutional constraints, both of which were especially true after the failed 2004 recall referendum. Corrales calls this, "crowding out the opposition." ${ }^{26}$ Ultimately, Chávez's death in March 5, 20I3 would leave Venezuela with a regime that not only reiterated features of thirty-year-long Puntofijismo, such as the politics of exclusion and rentier socialism, but also produced contingent dynamics of its own, such as an illiberal and authoritarian hybrid regime.

On April I9, 20I3, current President of Venezuela, Nicolás Maduro, inherited this complicated legacy. The vicious circles of pacted democracy and the petro-state have conditioned the calculus of Maduro's decision-making-what some Latin American observers have termed Madurismo. ${ }^{27}$ The petro-state's statist, oil-centric, and rentier development continue to define Venezuela's economy. Likewise, partidocracia furnished Maduro's government with selfsustaining practices, such as exclusionary politics, rentier socialism, and clientelism. But Chavismo, while conditioned by AD and COPEI's Puntofijista legacy, introduced its own dynamics such as control of the media, Manichean ideology, and the creation of a "high-stakes" political system such that the opposition is isolated. Of course, the petro-state can never be divorced from its political sibling (Puntofijismo, Chavismo, or Madurismo), especially when global oil prices crash, which they did in 2016 to $\$ 26$ a barrel. This would again provide a new opportunity for a shift in Venezuelan politics. As under Chávez, this would be a shift not toward liberal democracy but toward illiberalism and, increasingly, autocratic rule. Put this way, Maduro's current regime is the product of a decades-long combination of elite intentions, institutional legacies, and historical contingencies.

Of course, Madurista governance is not just a replay of Chavismo. Unlike Chávez, who used oil revenue to weaken oppositionists, Maduro has used political repression in the face of diminished oil revenues and scant savings. Since Maduro's narrow victory over MUD (Democratic Unity Roundtable) candidate Henrique Capriles in 2013, over 800 public protests have occurred in Caracas, mostly led by students like Gaby Arellano from Universidad de Los Andes. Maduro has correspondingly purged opponents and employed military repression. Moisés Naím calls this Venezuela's "Plan B: Strip virtually all power from every institution it [has] lost control of," namely the National Assembly, where the opposition obtained two-thirds of the seats in $2015 .{ }^{28}$ In response, in 2017 , Maduro jailed the mayor of Caracas (Antonio Ledezma) and fired both the Minister of Defense (Diego Molero) and the Minister of the Interior (Miguel Rodríguez Torres). ${ }^{29}$ Also, earlier in 2016 , when the opposition requested a recall referendum, the loyalist-dominated Supreme Court cancelled the process. By March 20I7, the Supreme Court nullified the National Assembly. ${ }^{30}$ A joint communique issued by several Venezuelan human rights NGOs (such as Todos Por La Libertad) reported a tally of over 400 political prisoners in December 20I7.3. Amnesty International reports that the military has been conducting arbitrary detentions and illegal raids. ${ }^{32}$ Opposition leader Lilian Tintori frequently uploads videos to her Instagram account (@liliantintori) featuring the police attacking protesters with bats, tear gas, water hoses, and marble pellets. ${ }^{33}$ In December 20I7, Maduro forbade certain opposition parties 
from participating in national elections. In short, Maduro's regime is distinguished by dictatorial, autocratic, and repressive one-man rule.

But Venezuela's crisis is not just political and economicit is also, more importantly, humanitarian. Poverty is now back to pre-Chávez levels. Infant mortality in 2016 increased 30 percent and maternal mortality 65 percent. Malaria, previously eradicated, has reemerged. Also in 2016, Venezuela saw its highest-ever number of homicides: $28,479 .{ }^{34}$ Juan Maragall, Secretary of Education in the northern department of Miranda, reveals that in the 20I6I7 academic year, approximately Io,००० students (mostly of age twelve and up) have left school to start employment and provide parents with supplementary household income to purchase groceries and other household necessities. ${ }^{35}$ Hundreds are now also fleeing to neighboring Colombia. \$ig6 billion in debt has prompted Venezuela to seek aid from Russia, as China's Sinopec in November 20I7 sued PDVSA for \$23.7B in unpaid loans..$^{36}$ In December 20I7, Maduro initiated negotiations with opposition leaders in the Dominican Republic on a six-point agenda, including the release of political prisoners. ${ }^{37}$ The nephews of the first lady, Efraín Flores and Franqui Freitas, have been jailed in the U.S. on drug charges. ${ }^{38}$ The list of cataclysms under Maduro are endless, but they all indicate one thing: Madurismo is neither Puntofijismo nor Chavismo. It is a quintessentially new phenomenon that Venezuela has never seen before. It is the latest chapter in the unraveling of a discredited pacted democracy, feeble petro-state, clamorous civil society, and hybridist Chavismo.

Ultimately, Venezuela is a country is crisis. Such contemporary tumult, this backgrounder has shown, is rooted in, conditioned by, and inseparable from Venezuela's midtwentieth century history. This history is one of Puntofijismo between AD and COPEI from I95 8 to I998, defined by two interrelated pillars: the petroestado (petro-state, an oildependent economy) and partidocracia (pacted democracy, a system of inter-elite bargaining). The former has rendered state-society relations in Venezuela dependent on the extraction and distribution of oil rent; the latter has created restricted political participation, corporatist civil society, patronage, presidentialism, and bloated bureaucracies. What happened during the I980s forewarned a forthcoming storm in Venezuela-one of social demand, radical reform, and high political competition. When oil prices dwindled in 1983 , civil society actors emerged calling for an overthrow of Puntofijismo and its exclusionary politics, and Hugo Chávez's Movimiento Revolucionario
Bolivariano (MRB) successfully channeled this demand into a democratically elected political project. This "Bolivarian Revolution," however, proved just as exclusionary and clientelistic through misiones bolivarianas, while simultaneously creating an illiberal hybrid regime via his rewritten 1999 Constitution. Nicolás Maduro has inherited this regime, but diminished oil revenues have caused him to become increasingly autocratic, purging political opponents, using military violence, isolating the country diplomatically, and engaging in drug trafficking. Venezuela is at a tipping point. The time has come for transitionto genuine democracy.

\section{ENDNOTES}

I. Moisés Naím, "Venezuela’s Democratic Façade has Completely Crumbled," Carnegie Endowment for International Peace, last modified July I, 20I6, http://ceip.org/2kyZ2ek

2. Daniel Hellinger, "Hugo Chávez and the Bolivarian Revolution in Venezuela," Oxford University Press, last modified May 28,

20I3, http://www.oxfordbibliographies.com/view/document/ obo-9780I9976658I/obo-9780I9976658I-0074.xml?rskey=960 $\mathrm{mHp} \&$ result $=\mathrm{I} \& \mathrm{q}=$ venezuela+crisis\#firstMatch

3. Javier Corrales, "Strong Societies, Weak Parties: Regime Change in Cuba and Venezuela in the I950s and Today," Latin American Politics and Society 43, no. 2 (200I): 8I-II4.

4. Terry Lynn Karl, The Paradox of Plenty: Oil Booms and Petrostates (Berkeley: University of California Press, I997), I6. 5. Ibid., 93.

6. Michael Coppedge, Strong Parties and Lame Ducks: Presidential Partyarchy and Factionalism in Venezuela (Stanford: Stanford University Press, I997).

7. Pedro Sanoja, "Ideology, Institutions and Ideas: Explaining Political Change in Venezuela," Bulletin of Latin American Research 28, no. 3 (2009): 394-410.

8. Daniel Hellinger, "Venezuelan Oil: Free Gift of Nature or Wealth of a Nation?" International Journal 62, no. I (2007): 59.

9. Thomas L. Friedman, "The First Law of Petropolitics," Foreign Policy, last modified October I6, 2009, http://foreignpolicy. com/2009/Io/I6/the-first-law-of-petropolitics/

ı. Daniel H. Levine, "The Decline and Fall of Democracy in Venezuela: Ten Theses," Bulletin of Latin American Research 2I, no. 2 (2002): 25 I.

II. Sanoja, "Explaining Political Change in Venezuela," 394. I2. Richard Lapper, "Venezuela and the Rise of Chávez: A Background Discussion Paper," Council on Foreign Relations, last modified November 22, 2005, https://www.cfr.org/ backgrounder/venezuela-and-rise-chavez-backgrounddiscussion-paper

I3. Ronald Chacín Fuenmayor, "Hacia una evaluación del pluralismo democrático en Venezuela: los partidos políticos y las agrupaciones sociales en el periodo I989-1993," Espacio Abierto IO, no. 2 (200I)

I4. Ernesto Laclau, On Populist Reason (London: Verso, 2005). 
I5. Barry Cannon, Hugo Chávez and the Bolivarian Revolution: Populism and Democracy in a Globalised Age (Oxford University Press, 2009).

I6. Julia Buxton, "Venezuela's Contemporary Political Crisis in Historical Context," Bulletin of Latin American Research 24, no. 3 (2005): 339 .

I7. Ibid., 328.

I8. Lapper, "A Background Discussion Paper."

I9. Margarita López Maya, "Venezuela: The Political Crisis of Post-Chavismo," Social Justice 40, no. 4 (20I4): 70.

20. Danielle Renwick, "Venezuela in Crisis," Council on Foreign Relations, last modified August I, 20I7, https://www.cfr.org/ backgrounder/venezuela-crisis

2I. Lacruz, Tito, "La propuesta social del gobierno bolivariano: Las misiones," In Una mirada sobre Venezuela: Reflexiones para construir una visión compartida (Caracas: Universidad Católica Andrés Bello, 2006): I7I-I82.

22. Buxton, "Venezuela's Contemporary Political Crisis," 346. 23. Javier Corrales and Michael Penfold-Becerra, Dragon in the Tropics: Hugo Chávez and the Political Economy of Revolution in Venezuela (Brookings Institution Press, 20II).

24. "Constitución de la República Bolivariana de Venezuela," Organization of American States, last modified I999, https:// www.oas.org/juridico/mla/sp/ven/sp_ven-int-const.html 25. Jean Francois Gagne, "Hybrid Regimes," Oxford University Press, last modified March Io, 20I5, http://bit.ly/2BwnKqe 26. Javier Corrales and Michael Penfold-Becerra, "Venezuela: Crowding out the Opposition," Journal of Democracy I8, no. 2 (2007): 99-II3.

27. Pedro Benítez, "En Venezuela muere el Chavismo y ahora vive el Madurismo," ALnavío, last modified Nov 3, 20I7, https:// alnavio.com/noticia/ı1875/firmas/en-venezuela-muere-el-

Chavismo-y-ahora-vive-el-Madurismo.html

28. Naím, "Venezuela's Democratic Façade."

29. Benítez, "Ahora vive el Madurismo."

30. Dany Bahar and Harold Trinkunas, "Io Things You

Should Know about the Current Crisis in Venezuela,"

Brookings Institution, last modified April 24, 20I7, http://brook. gs $/ 2$ qGnBv2

3I. "ONGs Venezolanos resaltan la dramática situación de los presos politicos," La Patilla, December I5, 20I7, http://bit. ly/2zgySFU

32. "Venezuela 20I6/20I7," Amnesty International, last modified 20I7, http://bit.ly/2jNDJ6Q

33. Lilian Tintori's official Instagram account can be accessed online here: https://www.Instagram.com/liliantintori/?hl=en 34. Barrette Janney and Myroslav Dobroshynskyi, "Panel Looks at Origins and Future of Venezuela Crisis," The Heights, last modified October 28, 20I7, http://bcheights.com/20I7/IO/28/ panel-looks-origins-future-venezuelan-crisis /

35. "Tristemente en Venezuela aumentan cifras por deserción escolar entre 20і6-20I7," El Político, last modified September 6, 20I7, http://www.elpolitico.com/tristemente-en-venezuelaaumentan-cifras-por-desercion-escolar-entre-20I6-20I7/ 36. Sherisse Pham, “China Sues Venezuela's Oil Company Over Unpaid Bills," CNN Money, last modified December 7, 20I7,
http://cnnmon.ie/2BjGklP

37. Valentín Romero, "Gobierno y oposción retomarán proceso de diálogo el II y I2 de enero," El Universal, last modified December I5, 20I7, http://bit.ly/2CHjiTw

38. "Sobrinos de Nicolás Maduro fueron condenados a I8 años por narcotráfico," Semana, last modified December I4, 20I7, http://www.Semana.com/nacion/articulo/eeuu-sobrinosde-primera-dama-de-venezuela-condenados-a-I8-anos-pornarcotrafico $/ 550684$

\section{REFERENCES}

Bahar, Dany and Harold Trinkunas. "Io Things You Should Know about the Current Crisis in Venezuela." Brookings Institution. Last modified April 24, 20I7, http:// brook.gs/2qGnBv2

Benítez, Pedro. "En Venezuela muere el Chavismo y ahora vive el Madurismo." ALnavío. Last modified Nov 3, 20I7, https://alnavio.com/noticia/ı1875/firmas/en-venezuelamuere-el-Chavismo-y-ahora-vive-el-Madurismo.html

Buxton, Julia. “Venezuela's Contemporary Political Crisis in Historical Context." Bulletin of Latin American Research 24 , no. 3 (2005): 328-347.

Cannon, Barry. Hugo Chávez and the Bolivarian Revolution: Populism and Democracy in a Globalised Age. Oxford University Press, 2009.

“Constitución de la República Bolivariana de Venezuela." Organization of American States. Last modified I999, https://www.oas.org/juridico/mla/sp/ven/sp_ven-intconst.html

Corrales, Javier. "Strong Societies, Weak Parties: Regime Change in Cuba and Venezuela in the I950s and Today." Latin American Politics and Society 43, no. 2 (200I): 8I-II4.

Corrales, Javier, and Michael Penfold-Becerra. Dragon in the Tropics: Hugo Chávez and the Political Economy of Revolution in Venezuela. Brookings Institution Press, $201 \mathrm{I}$.

Corrales, Javier, and Michael Penfold-Becerra. "Venezuela: Crowding out the Opposition." Journal of Democracy I8, no. 2 (2007): 99-II3.

Fuenmayor, Ronald Chacín. "Hacia una evaluación del 
pluralismo democrático en Venezuela: Los partidos políticos y las agrupaciones sociales en el periodo I989-I993." Espacio Abierto Io, no. 2 (200I).

Friedman, Thomas L. "The First Law of Petropolitics." Foreign Policy. Last modified October I6, 2009, http://foreignpolicy.com/2009/10/16/the-first-law-of-petropolitics/

Gagne, Jean Francois. "Hybrid Regimes." Oxford University Press. Last modified March Io, 2015, http://bit. ly/2BwnKqe

Hellinger, Daniel. "Venezuelan Oil: Free Gift of Nature or Wealth of a Nation?" International Journal 62, no. I (2007): $55-67$.

Hellinger, Daniel. "Hugo Chávez and the Bolivarian Revolution in Venezuela." Oxford University Press. Last modified May 28, 2013, http://www.oxfordbibliographies.com/ view / d ocument / obo- 978 o I 9976658 I / obo9780I9976658I-0074.xml?rskey=960mHp\&result $=\mathrm{I} \& q$ =venezuela+crisis\#firstMatch

Janney, Barrette and Myroslav Dobroshynskyi. "Panel Looks at Origins and Future of Venezuela Crisis." The Heights. Last modified October 28, 20I7, http://bcheights. $\mathrm{com} / 20 \mathrm{I} 7 / \mathrm{IO} / 28 /$ panel-looks-origins-future-venezuelancrisis/

Karl, Terry Lynn. The Paradox of Plenty: Oil Booms and Petro-States. Berkely: University of California Press, I997.

Laclau, Ernesto. On Populist Reason (London: Verso, 2005).

Lacruz, Tito. "La propuesta social del gobierno bolivariano: Las misiones." In Una mirada sobre Venezuela: Reflexiones para construir una visión compartida, I7I-I82. Caracas: Universidad Católica Andrés Bello, 2006.

Lapper, Richard. "Venezuela and the Rise of Chávez: A Background Discussion Paper." Council on Foreign Relations. Last modified November 22, 2005, http://on.cfr. org/2yJ5VIK

Levine, Daniel H. "The Decline and Fall of Democracy in Venezuela: Ten Theses." Bulletin of Latin American Re- search 2I, no. 2 (2002): 248-269.

Maya, Margarita López. "Venezuela: The Political Crisis of Post-Chavismo." Social Justice 40, no. 4 (2014): 68-87.

Naím, Moisés. "Venezuela's Democratic Façade has Completely Crumbled." Carnegie Endowment for International Peace. Last modified July I, 20I6, http://ceip.org/2kyZ2ek

"ONGs Venezolanos resaltan la dramática situación de los presos politicos.” La Patilla. December I5, 20I7, http://bit. ly/2zgySFU

Pham, Sherisse. "China Sues Venezuela's Oil Company Over Unpaid Bills." CNN Money. Last modified December 7, 20I7, http://cnnmon.ie/2BjGklP

Renwick, Danielle. "Venezuela in Crisis." Council on Foreign Relations. Last modified August I, 20I7, https://www. cfr.org/backgrounder/venezuela-crisis

Romero, Valentín. "Gobierno y oposción retomarán proceso de diálogo el iı y I2 de enero." El Universal. Last modified December I5, 20I7, http://bit.ly/2CHjiTw

Sanoja, Pedro. "Ideology, Institutions and Ideas: Explaining Political Change in Venezuela." Bulletin of Latin American Research 28, no. 3 (2009): 394-410.

"Sobrinos de Nicolás Maduro fueron condenados a I8 años por narcotráfico." Semana. Last modified December I4, 20I7, http:/www.Semana.com/nacion/articulo/eeuu-sobrinos-de-primera-dama-de-venezuela-condenados-aI8-anos-por-narcotrafico/550684

"Tristemente en Venezuela aumentan cifras por deserción escolar entre 20I6-20I7." El Político. Last modified September 6, 20I7, http://www.elpolitico.com/tristementeen-venezuela-aumentan-cifras-por-desercion-escolar-entre-20I6-20I7/

"Venezuela 20I6/20I7." Amnesty International. Last modified 20I7, http://bit.ly/2jNDJ6Q 